\title{
Cryopreservation of oocytes and embryos: implications on ART treatments
}

\section{Criopreservação de oócitos e embriões: implicações nos tratamentos de Reprodução Assistida}

\author{
Fabiany Marestone Gonçalves ${ }^{1}$, Vinicius Bonato da Rosa ${ }^{1}$, José Augusto Lucca Neto ${ }^{1}$, Alessandro Schuffner ${ }^{1}$ \\ ${ }^{1}$ Conceber - Centro de Medicina Reprodutiva - Curitiba - PR \\ Accredited Redlara centre
}

\section{RESUMO}

Atualmente muitos casais enfrentam dificuldades para engravidar. Os tratamentos de reprodução assistida têm sido uma das alternativas para alcançar a tão sonhada gravidez. Uma técnica utilizada como complemento ao tratamento de fertilização in vitro (FIV) é a criopreservação de oócitos e embriões. A tecnologia utilizada por mais de 10 anos foi o congelamento lento, contudo este método foi aprimorado e surgiu a vitrificação que demonstrou melhores resultados. A criopreservação de embriões segue como a principal escolha dos casais em tratamento de FIV e injeção intracitoplasmática de espermatozoides (ICSI), porém, a vitrificação de oócitos está se tornando uma tendência promissora por ser menos preocupante eticamente. Palavras chave: vitrificação, criopreservação, oócitos, embriões.

\section{ABSTRACT}

Today many couples struggling to get pregnant. The treatment of assisted reproduction has been one of the alternatives to achieve the long awaited pregnancy. A technique used to supplement the in vitro fertilization (IVF) treatment is the cryopreservation of oocytes and embryos. The technology used by more than 10 years was slow freezing, however, the method has been improved, so the vitrification has shown better results. Cryopreservation of embryos following as the top choice of couples undergoing treatment for IVF and intracytoplasmic sperm injection (ICSI), however, vitrification of oocytes is becoming a promising trend to be less ethically troubling.

Keywords: vitrification, cryopreservation, oocytes, embryos.

\section{INTRODUCTION}

A couple may be considered infertile if, after two years of regular sexual contact, without contraception, the woman has not become pregnant (WHO, 2010). For that reason, several couples are directed to assisted reproductive clinics in order to achieve the desired pregnancy.

In vitro fertilization (IVF) techniques are used couples seeking help to conceive and become pregnant. Besides these IVF techniques, oocyte and embryo cryopreservation are also an option that helps achieve this goal. The first cryopreservation technique used was the slow freezing which it is not considered ideal due to the formation of ice crystal that can be detrimental to cell viability (Assaf \& Rodrigues, 2003). Vitrification is another cryopreservation technique in which an ultra-rapid decrease in temperature is achieved. This strategy decreases formation of ice crystal and exposure time to high concentration of cryoprotectants (Fahy et al., 1984; Liebermann et al., 2002).

Embryo cryopreservation is usually indicated in cases of ovarian hyperstimulation syndrome (OHSS) (Selman et al., 2009) or for couples with surplus embryos. Cryopreserved embryos can be used by the own couple, can be donated to another couple or research otherwise kept cryopreserved (Brazilian Biosecurity Regulation, 2005).

Oocyte cryopreservation is indicated for fertility preservation (Kuwayama et al., 2005), complications due to (OHSS) or when fertilization is not possible due to lack of sperm (Jain \& Paulson, 2006).

Therefore, this review intends to exam the use of oocyte and embryo cryopreservation in daily practice of reproductive medicine.

In order to perform this review, electronic databases such as EMBASE, SCIELO, PUBMED, MEDLINE were used as well as the manual of the Latin American Network of Assisted Reproduction (RedLara)

\section{BIBLIOGRAPHY REVIEW}

Close to 3.5 million children were born by assisted reproductive techniques until 2008 (Wennerholm et al. 2009). In vitro fertilization is a complex technique that had it first success reported in England in 1978 (Steptoe \& Edwards, 1978) and now it is a worldwide treatment for infertility. Due to the development of in vitro fertilization techniques, a number of new possible treatments became available to the patients such as embryo donation, surrogate pregnancy, embryo cryopreservation and gamete micromanipulation. In the midst of such advancement, cryopreservation became a valuable tool in assisted reproductive treatments.

\section{CRYOPRESERVATION}

It is the preservation of oocytes and embryos under very low temperatures which allows new opportunities of pregnancy without the need to go through another ovarian stimulation and all associated risks (Hill \& Freeman, 2011). In the other hand, assisted reproductive clinics should have a strict quality control to prevent cross contamination through the liquid nitrogen (Gosden \& Nagano, 2002) and human errors during technical and stocking procedures. Prevention of accidents and planning for natural disasters should also be part of a program to guarantee the integrity of nitrogen tanks (Siegel-Itzkovich, 2003).

\section{EMBRYO CRYOPRESERVATION}

The improvement in cryopreservation techniques together with the goal of single embryo transfer have increased the number of embryos cryopreserved. Embryo cryopreservation is indicated in cases which the transfer needs to be postponed as in OHSS (Selman et al, 2009) and also could be a possibility for couples with surplus embryos. In Brazil, the resolution $\mathrm{n}^{\circ}$ 1.957, from December 15th, 2010 from the Federal Medical Council establishes that the maximum number of transferred embryos should be associated to women age (table 1).

Table 1. Number of embryos transferred according to age

\begin{tabular}{lc}
\hline Age & $\mathbf{N}$ embryos \\
\hline Women $<35$ & 02 \\
\hline Women 36 to 39 & 03 \\
\hline Women $>40$ & 04 \\
\hline
\end{tabular}

Copyright - Todos os direitos reservados a

SBRA - Sociedade Brasileira de Reprodução Assistida
Recebido em 07-01-2013

Aceito em 20-06-2013 
By the time human IVF clinics started to freeze embryos, there was a question about what type of cryoinjuries this technique could cause to the embryo. However, several evidences demonstrated that long periods of frozen stock did not cause harm to embryos (Machtinger et al., 2002). Most couples that perform assisted reproductive treatments decide to freeze their surplus embryos aiming to use them in the future if needed. However, a couple may give up the idea of transfer these frozen embryos. In that case it is possible to donate them to another couple (Schuffner \& Sanches, 2006) or to stem cell research (Brazilian Biosecurity Regulation, 2005). In Brazil, it is forbidden to dispose human embryos because they are considered a potential life (Brazilian Biosecurity Regulation, 2005).

\section{DONATION TO ANOTHER COUPLE}

A quick review of the literature showed a marked difference among several countries in relation to couple's desire to place their embryos available for donation. This could vary from 2\% (Cooper, 1996) to 11\% (Van Voorhis et al.,1999) in United States, $18 \%$ at Finlad (Soderstrom-Anttila et al., 2001) and 29\% at Denmark (Bangsboll et al., 2004). Moutel et al. (2002) showed that only $9 \%$ of couples donated their embryos to other infertile couples. The donated embryos are not genetically related to the couple that adopted them, however the women can accomplish the desire to become pregnant and to nurse a child. Also, several couples are not comfortable with the idea of having their embryos cared by an unknown person (Lanzendorf et al. 2010).

\section{RESEARCH DONATION}

Embryo donation for research it is an option in some countries. The use of human embryos for research can generate valuable information that may improve techniques and treatments used in reproductive medicine and also supply the embryonic stem cell field with an important source of new cells (Lanzendorf et al., 2010). A survey of 509 Australian couples that had their embryos frozen for about two years revealed that $10 \%$ of the men and $34 \%$ of the women would donate their surplus embryos to research (McMahon et al. 2003).

In Denmark, embryo donation to study infertility treatment was the only legal option until 2003. A year later, this use was also allowed for stem cell research. However, embryo donation to another infertile couple remains illegal (Bangsboll et al., 2004). In the US, embryo donation for research is not always an option. The reason is because the country or the research institution may not allow projects with human embryos or because there are no ongoing studies at that moment (Lanzendorf et al., 2010).

In Brazil, the production of new embryonic stem cells lines are allowed if the embryos used, with the couple's authorization, are unviable and frozen for longer than three years (Brazilian Biosecurity Regulation, 2005).

It is the researcher responsibility to inform the couple how the process of embryo donation will occur and how they will be used in research (Lanzendorf et al. 2010).

\section{ABANDONED EMBRYOS}

One of the consequences related to the increased number of frozen embryos is the issue of abandoned embryos. This occurs due to several reasons such as couple's divorce, lost of contact with clinics or death (Cattoli et al., 2004).

According to Vukadinovich (2000) there are close to 3.000 abandoned embryos in the US. The American Society of Reproductive Medicine (ASRM) defined abandoned embryos after five years since the last contact between the parents and the clinic. In this case embryos are considered abandoned and may be discarded.

The clinics should advise couples to carefully consider all option before deciding to begin an IVF cycle and therefore avoiding the buildup of abandoned embryos (New York State Task Force On Life And The Law, 2001). However, according to Lyerly et al. (2004), even with the correct guidance, several couples still show uncertainty to choose the final fate of their frozen embryos. Some couples mentioned lack of information while others reported that they recei- ved too much information. The experience acquired with an IVF cycle was mentioned by some couples as the reason to change their decision about the embryos while others said that they were not in the right state of mind to decide at that moment. Although there was a low rate of disagreement within a couple on the fate of frozen embryos (Boada et al. 2003), other studies showed a rate of $7 \%$.

A Swedish report showed that most couples planned to use their frozen embryos only in cases that pregnancy with fresh embryos were not achieved (Svanberg et., 2001). Leader (2004) observed that $72 \%$ of couples that did no use their frozen embryos had a successful pregnancy with fresh embryos. A couple that decided to freeze their surplus embryo may have changes in their lives that might also change the fate of the stocked embryos (Leader, 2004).

Due to the complexity of this issue because of the involvement of ethical, religious and psychological questions, several couples avoid the decision about the fate of their embryos leaving it to the multidisciplinary team (Melamed et al., 2009). Oocyte cryopreservation became a viable alternative to avoid these polemic issues.

\section{OOCYTE CRYOPRESERVATION}

Oocyte cryopreservation allows more possibilities for patients and services in reproductive medicine. IVF with cryopreserved oocytes became an alternative for several cases as in the preservation of infertility (Moutel et al., 2002). Oocytes from cancer patients can also be retrieved and cryopreserved before first chemotherapy. After the therapy, they can be thaw and fertilized for embryo production and transfer (Kuwayama et al., 2005). Oocyte cryopreservation is also an option for women who want to postpone pregnancy. This technique turns it possible to single women to preserve their fertility without the need of donated sperm or potential partner (Kutluk et al., 2006). It is also an advantage for complicated cases of OHSS or when it is not possible to perform IVF due to absence of viable sperm (Jain, Paulson 2006).

In a survey of IVF clinics, $51 \%$ reported that oocyte cryopreservation was offered to patients (Rudick et al. 2010). In the same study, it was observed a fertilization rate of $67 \%$ and a pregnancy rate of $31 \%$ with frozen oocyte, what it is in the same range of other clinics around the world. This is a clear evidence that oocyte cryopreservation is a viable and efficient procedure to be offered.

It is well understood that techniques that involve the creation of a new human life is surrounded by polemic issues related to ethical, legal, psychological and religious aspects (Melamed et al., 2009)..

\section{ETHICAL AND LEGAL ISSUES}

Oocyte cryopreservation decreased custody disputes because it uses only the female reproductive cell. Events involving death or divorce do not create a dispute because oocytes are not considered a human life like an embryo as there was no fusion with a male gamete (Castellotti, Cambiaghi, 2008).

A way to reduce polemic issues related to gamete and embryo cryopreservation was the introduction of well elaborated, clear and complete consent forms. These forms should have information about disposal of frozen material in cases of divorce, death, illness, aging, disability, disappearance or the couple's inability to find an agreement.

Couples should be advised to sign the consent forms related to the treatment performed. All the points in the document should be explained and well understood by the patient (Waldman, 2000).

Some countries have specific regulations for techniques in assisted reproduction. For example, in Germany (and Italy), embryo cryopreservation is not allowed. In Sweden, the use of embryos for research is allowed, with some restrictive rules, until day $14^{\text {th }}$ post fertilization. In Italy, embryo cryopreservation is not allowed (Melamed et al., 2009).

In Brazil there is no specific federal law that regulates assisted reproductive treatments. However, the Federal Medical Council published the resolution no 1.957 on November, 
2010 replacing the no 1.358 from 1992 . The resolution of 1992 already mentioned the need of the consent form that could and should be used in court decisions (Melamed et al., 2009). The new resolution brings important resolutions such as the one that limits the number of transferred embryos according to women age.

\section{PSYCHOLOGICAL ISSUES}

According to Melamed et al. (2009), a personal crisis may create anxiety and weaken the psychological structure of an individual. Consequently, infertility can be considered a potential traumatic situation on couple's life including sociocultural and psychological issues.

Some studies have suggested that absence of pregnancy in some IVF cycles may be related to the negative impact of the stress associated to the treatment. In one study, the presence of cryopreserved embryos increased the confidence in relation to the treatment among women submitted to IVF cycles. Therefore, if cryopreservation can reduce the stress, it is possible that even indirectly, the increased success rate of IVF cycle may happen trough a psychological mechanism. However, more studies are necessary to establish this relation of cryopreservation with psychological health (Koryntova et al., 2001).

Several psychological issues are associated with embryo donation: embarrassment for having an unknown biological child or unknown brother of your own child raised by another person (Tinney et al., 2002), some couples feel responsible for the care of any child conceived from their own embryos and cannot think about donating them to someone else (Lyerly \& Faaden, 2007), besides that couples that did not succeed in their own reproductive treatment, may not accept the possibility of having their genetic child care by another couple.

\section{RELIGIOUS ISSUES}

In a speech to the participants of the International Congress organized by The Pontifical Academy for Life, Pope Bento XVI said that each human being, since his conception, is a unit of body and soul, which has in itself the vital principle that will lead to the development of all his potential, not only biological but also anthropological. He also refers to the research with human embryos as an unfortunate initiative that results in the destruction of these embryos, turning them into laboratory objects. About cryopreservation, the Pope said that embryos are exposed to an absurd fate, without guarantee of survival and also mention the possible prenata adoption. From the moment of conception, the human being have rights and among them the right to life is the first one, because allows the continuation of all other rights.

\section{DISCUSSION}

According to Badalotti et al. (2003), embryo cryopreservation is the main choice for couples in IVF treatment; however, oocyte vitrification has become a promising trend among these couples.

The study from Hill e Freeman (2011) supports the notion that embryo adoption is an excellent alternative for patients that did not have success during IVF with their own gametes. They also demonstrated that embryo adoption is more financial advantageous than oocyte donation.

For several couples, these (frozen) embryos are possibilities and promises that in many cases may become the expected child. In this way, the desire to have its own child by this technique creates great anxiety for these couples. Common concerns:

Brzyski et al. (2000), reported that $11,4 \%$ of births came from cryopreserved embryo transfers. In another study, one group of embryos was transferred after 2-9 years frozen while another group was transferred after 6 months frozen. There was no difference in the survival rate of the two groups as well as implantation rate $(4,5 \%$ e 5,5\% Machtinger et al. 2002).

In a Spanish study, Boada et al. (2003) showed that the embryo was considered a "person" in different development stages: during pre-implantation, during implantation, on day 14 th of development and during birth.

\section{CONCLUSION}

The data suggests that strict control and care should be conducted by IVF clinics to avoid viral contamination.

Embryo cryopreservation involves a number of ethical questions that should be considered before couple's final decision. The couple should be aware that embryos will not be discarded and what are the possible fates, in case they decide not to use them in the future.

Oocyte cryopreservation, which has been an important tool in fertility preservation, it is a viable alternative to embryo cryopreservation because does not carry the same ethical and legal issues.

The introduction of consent forms became a solution for litigations because the couple defines the fate of the frozen material, especially in cases of divorce or death. Couples submitted to assisted reproductive treatments should sign these forms only after all questions were answered as well as the importance of the assessment of risks and benefits in order to avoid the increased number of cryopreserved embryos.

Cryopreservation became an important tool in assisted reproductive clinics, despite the polemic, ethical, psychological and religious issues.

In terms of religious issues, there is not a consensus and more discussion is necessary. Embryo cryopreservation and the fate of these embryos are not well regarded by the Church, as they are considered a potential human live. However it is necessary more studies and research on that issue.

\section{Corresponding Author}

Alessandro Schuffner

Clinica Conceber - Centro de Medicina Reprodutiva

Av. Republica Argentina, 210, $17^{\circ}$ andar

CEP: 80240-210

Curitiba - PR

alessandro@clinicaconceber.com.br

\section{REFERENCES}

Assaf, Ss; Rodrigues, Jl. Vitrificação de embriões Mus dimesticusdomesticuscontidos em volumes diferentes de 9,0 M de etileno glicol. 2003. 63 p. Dissertação (Mestrado em Ciências Veterinárias, na área de concentração em reprodução animal)Faculdade de veterinária, Universidade do Rio grande do Sul, Porto Alegre, 2003.

Badalotti, M; Farinati, D; Arent; Petracco, R; Petracco, A. Destino dos Oócitos Excedentes nos Programas de Fertilização Assistida. JBRA assist reprod. 2003; 7 (2).

Bangsboll S, Pinborg A, Yding Andersen C, Nyboe Andersen A. Patients' attitudes towards donation of surplus cryopreserved embryos for treatment or research. Hum Reprod. 2004; 19:2415-9.

Bento XVI, Papa. Pontifícia Academia Para A Vida. 2006. Disponível em: http://www.vatican.va/romancuria/pontificalacademies/acdlife/indexpo.htm

Boada M, Rodrigo C, Veiga A, Barri P. The future of frozen embryos: couples' point of view. Presented at: 19th Annual Meeting ESHRE; June 2003; Madrid, Spain.

Brzyski RG, Binkley PA, Pierce JD, Eddy Ca. Impact of implementation of an embryo storage fee on embryo disposal activity. Fertil Steril 2000;74:813-5

Castellotti, DS; Cambiaghi, AS. Preservação da fertilidade em pacientes com câncer. Rev Bras Hematol Hemoter, São Paulo. 2008; 30 (5): 406-410.

Cattoli M, Borini A, Bonu Ma. Fate of stored embryos: our 10 years experience. EJOG 2004;115(Suppl 1): S16-8.

Conselho Federal De Medicina Resolução No- 1.957, DE 15 DE DEZEMBRO DE 2010 disponível em: http://www.in.gov.br/ autenticidade.html

Cooper S. The destiny of supernumerary embryos (letter). Fertility and Sterility 1996;65:205

Fahy GM, Macfarlane DR, Angell CA, Meryman HT. Vitrification as an approach to cryopreservation. Cryobiol.1984; 21 : 407-426. 
Gosden R, Nagano M. Preservation of fertility in nature and ART. Hum Reprod. 2002;123:3-11.

Jain John K; Paulson Richard J. Oocyte cryopreservation. Fertil Steril. 2006; 86, Suppl 3.

Koryntova D, Sibrtova K, Klouckova E, Cepicky P, Rezabek K, Zivny J. Effect of psychological factors on success of in vitro fertilization [in Czechoslovakian]. Ceska Gynekol. 2001; 66:264-269.

Kutluk O., Aylin PC; Heejung. Efficiency of oocyte cryopreservation: a meta-analysis. Fertil Steril. 2006; 86, No. 1,

Kuwayama, M; Vajta, G; Kato, O; Leibo, Sp. Highly efficient vitrification method for cryopreservation of human oocytes. Reprod Biomed Online. 2005; 11:300-308.

Lanzendorf S; Ratts Valerie; Keller S; Odem Randall. Disposition of cryopreserved embryos by infertility patients desiring to discontinue storage. Fertil Steril. 2010; 93,No. 2.

Leader A. Research implications of embryo cryopreservation choices made by patients undergoing in vitro fertilization Fertil Steril. 2004; 81, NO. 4.

Lei De Biosseguranca - Lei 11105/05 | Lei no 11.105, de 24 de Março de 2005. Disponível em: http://www.jusbrasil.com.br/ legislacao/96812/lei-de-biosseguranca-lei-11105-05.

Liebermann J, Nawroth F, Isatchenko V, Isachenko E, Rahimi G, Tucker M. Potential importance of vitrification in reproductive medicine. Biol Reprod. 2002; 67:1671-1680.

Lyerly A, Brelsford E, Bankowski B, Faden R, Wallach E. A Qualitative study of individuals' attitudes regarding their cryopreserved embryos. Presented at: 18th World Congress on Fertility and Sterility, International Federation of Fertility Societies; 2004; Montreal.

Lyerly AD, Faaden RR. Willingness to donate frozen embryos for stem cell research. Sci. 2007; 317:46-47.

Machtinger R, Dor J, Levron J, Mashiach S, Levran D, Seidman Ds. The effect of prolonged cryopreservation on embryo survival. Gynecol Endocrinol. 2002; 16:293-298.

Mcmahon CA, Gibson FL, Leslie GI, Saunders DM, Porter KA, Tennant Cc. Embryo donation for medical research: attitudes and concerns of potential donors. Human Reproduction 2003; 18:871-7.

Melamed R. M, Seger L., Borges Jr., E. e Cols. Psicologia e Reprodução Humana Assistida: uma Abordagem Multidisciplinar. Livraria Santos Editora, 2009.

Moutel G, Gregg E, Meningaud Jp, Herve C. Developments in the storage of embryos in France and the limitations of the laws of bioethics. Analysis of procedures in 17 storage centres and the destiny of storedembryos. Med Law 2002; 21:587-604.
New York State Task Force On Life And The Law. Executive summary of assisted reproductive technologies: analysis and recommendations for public policy. Revisado em 2001. Disponível em: http://www.health.state.ny.us/nysdoh/taskfce/execsum.htm.

Rudick B., Opper N., Paulson R., Bendikson K., Bendikson, Chung K. The status of oocyte cryopreservation in the United States. Fertil Steril. 2010; 94, no 07

Schuffner A., Sanches M. A., Bioética e Doação de Embriões. Associação de obstetrícia e ginecologia do Paraná - SOGIPA News, 2006; $11: 4$

Selman H, Brusco GF, Fiorini F, Barnocchi N, Mariani M, El-Danasouri I. Vitrification is a highly efficient method to cryopreserve human embryos in in vitro fertilization patients at high risk of developing ovarian hyperstimulation syndrome. Fertil Steril. 2009; 91:1611-1613.

Siegel-Itzkovich J. Tel Aviv hospital destroys frozen embryos by mistake. BMJ. 2003; 326:12.

Soderstrom-Anttila V, Foudila T, Ripatti UR, Siegberg R. Embryo donation: outcome and attitudes among embryo donors and recipients. Hum Reprod 2001;16:1120-1128.

Steptoe PC, Edwards RG. Birth after the reimplantation of a human embryo. Lancet. 1978.

Svanberg A, Boivin J, Bergh T. Factors influencing the decision to use or discard cryopreserved embryos. Acta Obstet Gynecol Scand. 2001; 80(9):849-855.

Tinney L, Hammarberg K, Breheny S, Leeton J. Deciding the fate of excess frozen embryos. In: 21st Annual Scientific Meeting of the Fertility Society of Australia, Gold Coast, Australia (abstract). 2002 p.41.

Van Voorhis BJ, Grinstead DM, Sparks AE, Gerard JL, Weir RF. Establishment of a successful donor embryo program: medical, ethical, and policy issues. Fertil Steril.1999; 71:604-608.

Vukadinovich DM. Assisted reproductive technology law. Obtaining informed consent for the commercial cryopreservation of embryos. J Leg Med 2000; 21:67-78.

Waldman EA. Disputing over embryos: of contracts and consents. Ariz State Law J 2000; 32:897-940.

Wennerholm, Ub; Soderstrom-Anttila, V; Bergh, C; Aittomaki, K; Hazekamp, J; Nygren, KG; Selbing, A; Loft, A. Children born after cryopreservation of embryos or oocytes: a systematic review of outcome data. Hum Reprod. 2009; 24 (9): 2158-2172.

World Health Organization, 2010. 